\title{
Etnicidade e ensino de História: a matriz cultural africana*
}

\author{
Elio Chaves Flores ${ }^{* *}$
}

O ensaio discute o ensino de História da África na cultura escolar a partir de dois campos de produção e representações étnico-raciais: o estado da arte na universidade e a recente legislação sobre as questões étnico-raciais em relação à História da África. Parto da hipótese de que as estruturas curriculares dos cursos de História reproduzem para a educação básica o cânone da mestiçagem. O grande desafio para os estudos africanistas seria, portanto, ultrapassar os limites da seleção cultural.

Palavras-chave: Africanismo - Ensino de História - Questão racial

Ethnicim and history teaching: the african cultural heritage

This essay discusses the teaching of African History in the school system taking into account two different areas of ethnic-racial production and representation: the state of art at universities and the recent legislation on ethnic-racial in relation to African History. We depart from the hypothesis that curricular structures of History courses reproduce in basic education the canon of hybridity. So, the big challenge for African studies is to go beyond the limits of cultural selection.

Keywords: African studies - History teaching - Racial issues

Ethnicité et l'enseignement d'histoire: la matrice culturelle africaine.

Cet article discute l'enseignement de l'histoire de l'Afrique dans le domaine scolaire à partir de deux champs de production et de représentations ethnique-raciales : la situation à l'université et la législation récente sur les questions ethnique-raciales concernant l'histoire de l'Afrique. On part de l'hypothèse que les structures des programmes d'histoire reproduisent pour l'éducation fondamentale le canon du

\footnotetext{
*Artigo recebido em abril de 2006 e aprovado para publicação em junho de 2006.

${ }^{* *}$ Professor Adjunto do Departamento de História da Universidade Federal da Paraíba. Email: elioflores@terra.com.br.
} 
métissage. Pour les études africanistes, le plus grand défi serait, donc, de dépasser les limites de la sélection culturelle.

Mots-clefs: Africanisme - Enseignement d'histoire - Question raciale

\section{Introdução}

O presente trabalho discute o ensino de História da África na cultura escolar brasileira a partir de dois campos de produção e representações étnico-raciais: a pesquisa e o ensino na universidade e a recente legislação sobre as questões étnico-raciais na escola básica. Parto do pressuposto de que as estruturas curriculares dos cursos de graduação em História, no Brasil, ficaram, por muito tempo, presas ao foco eurocêntrico dos conteúdos historiográficos. A própria pesquisa histórica, com a multiplicidade de temas e abordagens nos últimos 25 anos, ainda não conseguiu estimular a alteridade curricular e mudar uma cultura acadêmica e escolar na qual a África e o africanismo aparecem apenas nos contextos da escravidão e da expansão do capitalismo.

No século XX, o continente africano ainda recebe um naco de parágrafos na historiografia da educação básica, quando, com o fim da Segunda Guerra Mundial, as guerras de independência dos países africanos entram na seara da história contemporânea como a dimensão periférica da Guerra Fria. Esta cultura escolar viria a ser enfrentada somente depois da Constituição de 1988, que tornou possível a criminalização do racismo no Brasil.

\section{Um problema de pesquisa e ensino na universidade}

Quem já não ouviu um candidato a qualquer cargo eletivo no Brasil afirmar pomposamente que sua velha empregada era uma Mãe Preta? Que ela, na infância, lhe curava a dor de dente com um ritual de benzedeira e galhos de arruda? Mas esta Mama África (negros e pardos) continua segregada nas favelas, nos terreiros e nos subúrbios de cidades cosmopolitas e, em certas situações, serve de objeto de dissertações e teses da sociologia e da antropologia interessadas. Como na cultura política familista, o mérito acadêmico não passa do reforço do privilégio sobre a carência e o preconceito. Em vez de uma universidade aberta e sensível às novas demandas sociais, temos uma universidade administrada para e pelo passado. Não é nenhum anacronismo 
afirmar que, na nossa cultura universitária, a meritocracia ainda é atributo e prerrogativa dos socialmente escolhidos. ${ }^{1}$

No campo da História, não seria muito difícil sustentar a tese de que, excetuando-se os estudos sobre o tráfico e a escravidão, a África e o africanismo foram muito pouco considerados por nossa tradição historiográfica. Quando não há informação adequada e pesquisa suficiente, o passado escravocrata insiste em não arredar pé da ambiência escolar; e o que se observa é um continente desconhecido ou, tomando emprestado a metáfora de Zé Ramalho, a mancha de um asteróide pequeno. Hélio Santos analisa o círculo vicioso destas representações escolares:

Apesar de a cultura negra ser a energia que dá ritmo à vida nacional, considerando ainda a dívida imensa do Brasil para com a África, não se observa uma equivalência desses pesos na vida e na política. Não é um exagero considerar um escândalo a ignorância em relação à África. [Ainda, segundo o autor,] (...) a grande maioria dos brasileiros considera o continente africano como um bloco homogêneo: tudo igual e todos negros. Quando muito, separam a África do Norte, que é árabe, daquela situada abaixo do deserto do Saara, também chamada África Negra. ${ }^{2}$

A Lei n ${ }^{\circ} 10.639$, de 9 de janeiro de 2003, torna obrigatório o ensino de História e Cultura Afro-Brasileira nos estabelecimentos de ensino fundamental e médio. Parte-se do pressuposto de que os cursos de graduação em História teriam a obrigação de ofertar disciplinas, tópicos especiais e seminários referentes à História da África e do africanismo para que o espírito da lei se torne uma prática curricular. Para que isto seja levado adiante, as bases curriculares dos cursos de História devem ser pensadas com ênfase nas espacialidades e nas durações históricas e não exatamente nas linearidades cronológicas. Decerto que a institucionalidade do processo não acaba com a lei na sala de aula, entretanto, contribui na construção da negritude e avança sobre os referenciais curriculares da etnicidade na história que se afirma no tempo presente como diversidade cultural. Trata-se de um programa em que o ensino da matriz

\footnotetext{
${ }^{1}$ Maurício Tragtenberg, "A delinqüência acadêmica", Sobre Educação, Política e Sindicalismo, São Paulo, Unesp, 2004, p. 11-19. Discussões mais contemporâneas em Marilena Chaú́, Escritos Sobre a Universidade, São Paulo, Unesp, 2001; e Maria do Carmo de Lacerda Peixoto (org.), Universidade e Democracia: experiências e alternativas para a ampliação de acesso à Universidade pública brasileira, Belo Horizonte, Editora UFMG, 2004.

${ }^{2}$ Hélio Santos, A Busca de um Caminho para o Brasil: a trilha do círculo vicioso, São Paulo, Editora Senac, 2001, p. 247.
} 
cultural africana se constituiria numa barreira propedêutica contra o racismo à brasileira. ${ }^{3}$ Portanto, caberia à comunidade de historiadores uma maior contribuição para a superação de se pensar a África e o africanismo nos limites de um antropologismo tardio.

Pode-se definir este antropologismo tardio como a persistência de um processo de mestiçagem natural, democracia racial, sociabilidades lúdicas, em que o mundo afro-brasileiro não escaparia do samba, do futebol e da malandragem. Este mundo, ainda crivado de exotismo e superstição, seria um fomentador de rituais e crenças ilógicas que arrastariam a matriz africana para longe de qualquer plausibilidade científica. ${ }^{4}$ Deste modo, a África surge na estrutura curricular num recorte historiográfico nada singular: os portugueses circunavegam o continente etíope em busca do Oriente. Mas os africanos vendem escravos e os portugueses viajam para comprá-los. O mundo atlântico faz o resto: capitalismo, escravidão, tráfico de gente, Brasil. Os séculos coloniais, ontogênese de homens de fino trato, plasmariam, até que enfim, uma "doce escravatura", terminada pela generosa mão de uma não menos encantadora e alva princesa, em maio de $1888 .{ }^{5}$ Aqui, o teor africanista sai da cena da história: fim da escravidão, proclame-se então o branqueamento. A República, velha ou nova, não tratará dos negros. Esta dramática questão étnica, que atravessa a educação republicana, tem um pouco da construção e da prática historiadora em torno do "mito da democracia racial no Brasil". 6 Cabe ressaltar que o mito das três raças (democracia racial) não está só no nosso panteão de mitologias políticas, pois ele se encontra enraizado com o mito da tropicologia (por natureza, o Brasil é um paraíso) e com o mito do

\footnotetext{
${ }^{3}$ Ver Eliane Cavalleiro (org.), Racismo e Anti-Racismo na Educação: repensando nossa escola, São Paulo, Selo Negro, 2001; Gevanilda Santos e Maria Palmira da Silva (orgs.), Racismo no Brasil: percepções da discriminação e do preconceito racial no século 21, São Paulo, Editora Fundação Perseu Abramo, 2005.

${ }^{4}$ Trata-se, a rigor, das concepções européias e novo-mundistas da África. Um conhecido intelectual de Gana, talvez o mais influente da África Ocidental, quando os seus interlocutores descobrem que ele é filósofo, logo se espantam: "Nossa, você deve ser muito inteligente". Kwame Anthony Appiah, Na Casa de Meu Pai: a África na filosofia da cultura, Rio de Janeiro, Contraponto, 1997, p. 131.

${ }^{5}$ Esta mitologia racialista ganha notoriedade em comparação com os Estados Unidos, visto como o país da violência racial, e o Brasil, como o paraíso da tolerância racial. Estes excepcionalismos são comparados por Célia Maria Marinho de Azevedo, Abolicionismo: Estados Unidos e Brasil, uma história comparada (século XIX), São Paulo, Annablume, 2003.

${ }^{6}$ Emília Viotti da Costa, Da Monarquia à República: momentos decisivos, São Paulo, Editora Unesp, 1998, p. 365-384.
} 
populismo (a politicagem como destino manifesto). Os dois primeiros, cheios de positividades intrínsecas, e o último, carregado de uma maldição que não cessa, um passado que não passa. ${ }^{7}$

No mundo lusitano, o continente africano seria antes uma representação cartográfica para os navegadores portugueses. Vejam-se alguns pontos arrolados num volumoso dicionário de língua portuguesa: "conhecimento da África antes dos descobrimentos; descobrimentos do litoral; viagens e explorações do interior". ${ }^{8}$ Neste caso, haveria a necessidade de se romper com a divisão da história eurocêntrica e partida nas quatro colossais cronologias: antiga, medieval, moderna e contemporânea. Esta tradição curricular francesa, infelizmente ainda predominante nos cursos de História das universidades brasileiras, impede que o ensino de História da África se liberte das "armadilhas do quadripartismo histórico". 9

Entretanto, faça-se justiça aos historiadores franceses, pois Fernand Braudel (1902-1985), o mais influente deles, iria propor um ensino de História mais pluralista e menos etnocêntrico. Em vez de idades cronológicas, pensou-se em durações, economias, cultura material, povos, capitalismo triangular. Tendo sido residente e pesquisador na África mediterrânica e observador atento do processo de descolonização da África, na década de 1960, Braudel escreveu um livro para jovens estudantes, inserindo nas suas análises "o continente negro" e explicando as tendências do tempo presente na "África Negra de hoje [1963] e amanhã". Suas observações sobre as diásporas africanas estimulam a pesquisa e o ensino de temas africanistas: "é de notar-se o fato, importante para o mundo negro atual, de que existem Áfricas vivas no Novo Mundo. Fortes núcleos étnicos se desenvolveram e se perpetuaram até nossos dias no norte e no sul da América, ao passo que nenhuma destas Áfricas exiladas sobreviveu na Ásia ou em terras do Islã". ${ }^{10}$ Com efeito, os afro-brasileiros sofrem uma espécie de seleção cultural e quase não aparecem nos conteúdos

\footnotetext{
${ }^{7}$ Ver o excelente ensaio de Angela de Castro Gomes, "História, historiografia e cultura política no Brasil", Rachel Soihet, Maria Fernanda B. Bicalho e Maria de Fátima S. Gouvêa (orgs.), Culturas Políticas: ensaios de história cultural, história política e ensino de história, Rio de Janeiro, Mauad, 2005, p. 21-44.

${ }^{8}$ Teixeira da Mota, "África”, Dicionário da História de Portugal, Vol. I (Dir. Joel Serrão), Porto, Livraria Figueirinhas, s/d, p. 52-59.

9 Jean Chesneaux, Devemos fazer tábula rasa do passado? Sobre a história e os historiadores, São Paulo, Editora Ática, 1995, p. 92-99.

${ }^{10}$ Fernand Braudel, Gramática das Civilizações, São Paulo, Martins Fontes, 1989, p. 140.
} 
e nos currículos de História, especialmente na duração republicana, na qual impera o cânone da mestiçagem. ${ }^{11}$

O cânone da mestiçagem enrosca-se nos paradigmas científicos, no ensino superior e no acesso à qualificação da população afro-brasileira. Um exemplo desta situação seria o fato de as pesquisas dos últimos 20 anos sobre africanismo no Brasil terem sido duramente criticadas pelo combativo sociólogo francês Pierre Bourdieu (1930-2003) como a "difusão da doxa racial norte-americana no seio do campo universitário brasileiro, tanto no plano das representações, quanto das práticas”. Bourdieu, que demonstra simpatia pela sociologia de Gilberto Freyre, advoga que a identidade racial no Brasil não implica "ostracização radical nem estigmatização sem remédio". E denuncia os estudos sobre a matriz cultural africana no Brasil:

a Fundação Rockefeller financia um programa sobre "Raça e etnicidade" na Universidade Federal do Rio de Janeiro, bem como o Centro de Estudos Afro-Asiáticos (e sua revista Estudos Afro-Asiáticos) da Universidade Cândido Mendes, de maneira a favorecer o intercâmbio de pesquisadores e estudantes. Para a obtenção de seu patrocínio, a fundação impõe como condição que as equipes de pesquisa obedeçam aos critérios de affirmative action à maneira americana, o que levanta problemas espinhosos já que, como se viu, a dicotomia branco/negro é de aplicação, no mínimo, arriscada na sociedade brasileira. ${ }^{12}$

Embora Bourdieu tenha alguma razão quando tece críticas ao capital científico e ao financiamento de pesquisas étnico-raciais, ele parece não considerar que esta parcela da população afro-brasileira, que estuda e se torna cientista,

\footnotetext{
${ }^{11}$ Basta lembrar a famosa argumentação gilbertiana: "O 15 de novembro no Brasil não foi senão o periquito sociológico em relação com o papagaio: o 13 de Maio. (...) Porque a parte mestiça ou negróide da população, outrora escrava ou ainda servil, esta nunca se deixara seduzir pela República: aceitara-a apenas. Conformara-se com suas inovações sem perder o velho apreço pelo Imperador e a veneração quase mística pela Princesa Isabel, a Redentora”. Gilberto Freyre, Ordem e Progresso, Rio de Janeiro, Record, 1990, p. 298-301. Nos últimos 30 anos o cânone foi revisitado e criticado em diferentes campos. Ver Thomas Skidmore, Preto e Branco: raça e nacionalidade no pensamento brasileiro, Rio de Janeiro, Paz e Terra, 1976; Roberto Ventura, Estilo Tropical: história cultural e polêmicas literárias no Brasil, São Paulo, Companhia das Letras, 1991; Kabengele Munanga, Rediscutindo a mestiçagem no Brasil: identidade nacional versus identidade negra, Belo Horizonte, Editora Autêntica, 2004; e Benjamin Abdala Junior (org.), Margens da Cultura: mestiçagem, hibridismo \& outras misturas, São Paulo, Boitempo, 2004.

${ }^{12}$ Pierre Bourdieu e Löic Wacquant, "Sobre as artimanhas da razão imperialista", Escritos de Educação, Petrópolis, Vozes, 1998, p. 17-32. O mesmo artigo foi republicado no Brasil na revista Estudos Afro-Asiáticos, Vol. 24, no 1, Rio de Janeiro, 2002, p. 15-33.
} 
possua qualquer dimensão protagonista; que o acadêmico afro-brasileiro, uma vez financiado pelo imperialismo americano, não pudesse mais contestá-lo, tornando-se um cientista dócil. Assim também foram vistos seus ancestrais africanos, escravos dóceis de senhores cordiais.

Esta é, a meu ver, a "estigmatização sem remédio" do ensino superior no Brasil, a de que os poucos afro-brasileiros estariam fora de seus lugares quando, por méritos acadêmicos, conquistam o acesso à universidade, às salas de aula e aos laboratórios de pesquisa. Pierre Bourdieu, um notável intelectual militante das causas sociais, foi surpreendido pelo cânone da mestiçagem, e seu estranhamento sobre o protagonismo dos afro-brasileiros lembra a mesma situação dos interlocutores do filósofo de Gana, Kwame Appiah: "Nossa! Basta dar-lhes oportunidade que os negros brasileiros estudam e pesquisam!" Inobstante, as polêmicas levantadas pelas idéias do sociólogo francês ajudaram a construir pontes entre cientistas sociais e historiadores sobre a África e o africanismo na diáspora. $\mathrm{O}$ importante na pesquisa e no ensino das relações étnico-raciais talvez não seja a origem nem as artimanhas do financiamento, mas as matrizes curriculares e os conteúdos historiográficos. ${ }^{13}$ Importa, pois, asseverar o princípio de que o colonialismo seria, antes, o avesso da colonização. Esta tese, formulada pelo historiador Marc Ferro, considera que, no início do século XXI, especialmente depois de 11 de setembro de 2001, as dramáticas realidades causadas pela colonização e os seus corolários contemporâneos, como o neocolonialismo, a globalização e o imperialismo cultural e científico, "abrangem ao mesmo tempo os territórios e as populações antes dominadas e igualmente as metrópoles, assim como seus anticolonialistas. O cruzamento dessas situações explica outro fato: o de que uma parte desse passado está proibida de história". 14 Trata-se, portanto, de ver como as determinações jurídicas, em curso no Brasil, apontam para a transição curricular do cânone mestiço para a diversidade cultural. ${ }^{15}$

\footnotetext{
${ }^{13}$ Com textos rápidos e extremamente objetivos, análises de historiadores que ministram a disciplina História da África em algumas universidades brasileiras podem ser vistas na seção "História da África nos currículos: o que pensam os especialistas", Maria José Rocha e Selma Pantoja (orgs.), Rompendo Silêncios: História da África nos currículos da educação básica, Brasília, DP Comunicações, 2004, p. 19-63.

${ }^{14}$ Marc Ferro (org.), O Livro Negro do Colonialismo, Rio de Janeiro, Ediouro, 2004, p. 40.

${ }^{15}$ Proposta para uma estrutura curricular que contemple a matriz cultural africana nos cursos de graduação em História pode ser vista em Elio Chaves Flores, "Currículo e Diversidade Cultural: África e africanismo em História", Anais Eletrônicos do I Colóquio Internacional de Políticas Curriculares, João Pessoa, Centro de Educação/UFPB, 12 a 14 de novembro de 2003.
} 


\section{Lutas culturais e jurídicas em torno de currículos e conteúdos}

Além da criminalização do racismo, a Constituição de 1988 produziu importantes elementos para reconsiderações curriculares que tardaram a chegar ao universo escolar. Pesquisadores das questões raciais contemporâneas na República consideram que o projeto de igualdade racial contido na Constituição de 1988 chega a ser imponente. Surgiu uma nova representação da África na concepção da nacionalidade brasileira. Passaram a ser considerados brasileiros, por exemplo, os naturalizados "que, na forma da lei, adquiram a nacionalidade brasileira, exigida aos originários de países de língua portuguesa" (art. 12, II). Nos ordenamentos jurídicos anteriores, esta prerrogativa só cabia aos nascidos em Portugal. O Estado brasileiro, ao reconhecer a lusofonia, garante aos africanos nascidos em Angola, Moçambique, Guiné-Bissau, Cabo Verde e São Tomé e Príncipe a mesma condição para a nacionalidade. ${ }^{16} \mathrm{O}$ Estado passa a proteger "as manifestações culturais indígenas e afro-brasileiras", tornando imperativo que se fixem "as datas comemorativas de alta significação para os diferentes segmentos nacionais" (art. 215). ${ }^{17}$ Ações jurídicas do presente, que colocam desafios para o historiador, uma vez que é pelo ensino de História que as pessoas podem saber "o que aconteceu, por que aconteceu e, conseqüentemente, como as políticas públicas que provêm de acontecimentos históricos ou modelam esses acontecimentos podem servir ao bem comum". ${ }^{18}$

No caso da efeméride, a lei apenas referendava uma ruptura dos movimentos afro-brasileiros da década de 1970 que, repudiando a história oficial do Abolicionismo, passaram a reconhecer o 20 de novembro como o dia da libertação, elegendo Zumbi dos Palmares como o negro de maior significação simbólica na construção da liberdade. A virada pela instituição de uma nova história torna-se fundacional para o protagonismo negro no Brasil contempo-

\footnotetext{
${ }^{16}$ Creio que esta situação se estendia aos nascidos em Macau e Goa, que passaram a ter uma outra realidade institucional na década de 1990. Mas se enquadra na condição o Timor-Leste que, independente da Indonésia, se constitui como país de língua portuguesa. O Ministério da Educação do Brasil, mediante convênio em 2004, enviou vários profissionais para que o país recupere mais rapidamente a antiga língua do colonizador.

${ }^{17}$ Ver a excelente análise jurídica em Hédio Silva Jr., "Do racismo legal ao princípio da ação afirmativa: a lei como obstáculo e como instrumento dos direitos e interesses do povo negro", Antonio Sérgio Alfredo Guimarães e Lynn Huntley (orgs.), Tirando a Máscara: ensaios sobre o racismo no Brasil, São Paulo, Paz e Terra, 2000, p. 359-387.

${ }^{18}$ John Hope Franklin, "O Historiador e a Política do Estado", Raça e História: ensaios selecionados (1938-1988), Rio de Janeiro, Editora Rocco, 1999, p. 379.
} 
râneo. ${ }^{19}$ Este direito à história e, portanto, ao passado e ao presente permitiu que se pudesse resgatar aquilo que Fernand Braudel chamou de "as Áfricas vivas no Novo Mundo", pois o art. 216 determinou: "ficam tombados todos os documentos e sítios detentores de reminiscências históricas dos antigos quilombos". O Estado passou a ter a obrigação de reconhecer e emitir títulos de propriedade da terra às comunidades remanescentes: comunidades rurais negras e comunidades quilombolas.

Com efeito, foi no título das Disposições Constitucionais Gerais que o legislador incorporou as práticas e as representações dos movimentos sociais indigenistas e africanistas. Gravou-se na lei maior que "O ensino de História do Brasil levará em conta as contribuições das diferentes culturas e etnias para a formação do povo brasileiro" (art. 242). Afirma-se, portanto, o caráter pluriétnico da sociedade brasileira; e o ensino de História deveria considerar as matrizes culturais da formação do Brasil. A persistência do cânone da mestiçagem não impediu que estas pequenas revoluções jurídicas apontassem para a história do Brasil multirracial e se descobrisse a tessitura histórica do Atlântico negro. ${ }^{20}$ Muitos pesquisadores anteciparam os pressupostos jurídicos, outros fizeram avançar a idéia de que, sem a historicidade da África e dos afro-brasileiros, as temporalidades do Brasil ficariam incompletas e, quiçá, ininteligíveis. ${ }^{21}$

\footnotetext{
${ }^{19}$ A instituição do Dia Nacional da Consciência Negra em 20 de novembro foi proposta no início da década de 1970 pelo poeta Oliveira Silveira, do Grupo Palmares do Rio Grande do Sul, então um forte reduto do Movimento Negro, onde o cânone da mestiçagem sempre fora repelido pelas próprias condições históricas da colonização do Brasil meridional. Sobre o movimento negro republicano, ver Abdias do Nascimento e Elisa Larkin Nascimento, "Reflexões sobre o movimento negro no Brasil, 1938-1997", Tirando a Máscara, op. cit., p. 203-235. Para uma reflexão sobre as lutas simbólicas entre o 13 de maio e o 20 de novembro, ver os artigos de Célia Maria Marinho de Azevedo, "13 de Maio e Anti-Racismo" e "Quem precisa de São Nabuco?", AntiRacismo e Seus Paradoxos: reflexões sobre cota racial, raça e racismo, São Paulo, Annablume, 2004, p, 87-93 e 97-106, respectivamente.

${ }^{20}$ No prefácio à edição brasileira de seu clássico livro, o sociólogo inglês Paul Gilroy fala sobre os impactos dos movimentos negros do Brasil e de suas lutas: "Falar do Brasil produz, corretamente, hesitação. Tudo o que eu normalmente quero dizer sobre a cultura e a mistura, a diáspora, a história e a sociabilidade transafricana tem uma ressonância diferente quando se refere a um lugar tão próximo do epicentro da escravidão racial moderna. (...) Aqueles processos ao mesmo tempo trans e interculturais são importantes e urgentes demais para serem discutidos por nós, para que permitamos que eles caiam na árida poesia de uma academia desinteressada". Paul Gilroy, O Atlântico Negro: modernidade e dupla consciência, Rio de Janeiro, Editora 34; Centro de Estudos Afro-Asiáticos/UCAM, 2001, p. 10.

${ }^{21}$ Caberia destacar a presença do historiador-diplomata Alberto da Costa e Silva, "Quem fomos nós no século XX: as grandes interpretações do Brasil", Carlos Guilherme Mota (org.), Viagem Incompleta: a grande transação, São Paulo, Editora Sesc, 2000, p. 17-40; do mesmo autor, Um Rio Chamado Atlântico: a África no Brasil e o Brasil na África, Rio de Janeiro, Nova Fronteira, 2003. Ver, também, Luís Rodolfo Vilhena, "África na Tradição das Ciências Sociais no Brasil”, Ensaios de Antropologia, Rio de Janeiro, Editora Uerj, 1997, p. 127-166.
} 
Na década de 1990, com a regulamentação de muitos artigos da Constituição de 1988 e, especialmente, com a entrada em vigor da nova Lei de Diretrizes e Bases da Educação Nacional, passou-se à elaboração dos Parâmetros Curriculares Nacionais para a Educação Básica. De modo que, ao final do século XX, os educadores se defrontaram com a propalada diversidade cultural na estrutura curricular e com os temas transversais no que concerne aos conteúdos das disciplinas. Passo então a examinar estes documentos institucionais, os impactos no ensino de História e suas reverberações na própria produção historiográfica a partir da temática etnicidade.

Não resta dúvida de que a Lei n ${ }^{\circ}$ 9394/96 consolidou diretrizes e bases pluriétnicas para a educação brasileira. Ela tornou imperativo que o ensino de História do Brasil levasse em conta as contribuições das diferentes culturas e etnias para a formação do povo brasileiro, "especialmente das matrizes indígena, africana e européia” (art. 26, $4^{\circ}$ ). As populações indígenas, por exemplo, mereceram artigos específicos sobre "educação escolar bilíngüe e intercultural". ${ }^{22}$ Outro documento importante é o primeiro volume dos Parâmetros Curriculares Nacionais que, na verdade, apresenta as diferentes áreas do conhecimento. Prescreve a abordagem das questões sociais urgentes através dos temas transversais, destacando-se a "pluralidade cultural", e propõe que o projeto educativo da escola se assente a partir da diversidade. A pluralidade cultural é entendida como a valorização da sociedade plural, com a perspectiva de que a desigualdade não pode ser confundida com a diversidade. Este princípio é, por suposto, republicano: o fato de que a escola deve ter como valor "o respeito às diferenças e não o elogio à desigualdade". ${ }^{23}$ Mas aí é que está a armadilha da situação, pois a desigualdade brasileira, historicamente unificada pelo triunfo da mestiçagem, tornou-se profundamente diversa: gendrada, étnica, econômica e regional (menina negra, pobre, nordestina). Não se trata mais de discursar sobre as heranças da escravidão, mas quebrar a trilha do círculo vicioso a partir de uma ironia instaurada na própria cultura

\footnotetext{
${ }^{22}$ Arts. 78 e 79 (Das Disposições Gerais). A votação da Lei n ${ }^{\circ} 9.394 / 96$ ocorreu no dia 17 de dezembro de 1996. Foi aprovada por 349 parlamentares; 73 votaram contra e houve 4 abstenções. O texto final da lei foi duramente criticado por entidades dos campos acadêmico, científico e sindical. Parte destas críticas está nos seguintes documentos: FNDEP, $L D B$ - Avaliação do Fórum Nacional em Defesa da Escola Pública, Belo Horizonte, 1997; e APUBH, A Nova LDB, Belo Horizonte, Associação Profissional dos Docentes da UFMG, 1997.

${ }^{23}$ MEC, Introdução aos Parâmetros Curriculares Nacionais, Vol. 1, Brasília, Secretaria de Educação Fundamental, 1998, p. 60-61, 68-69 e 92-93.
} 
escolar: "a Escandinávia é aqui?". ${ }^{24}$ Parece ser este o limite das diretrizes institucionais para um currículo e uma escola republicanamente multiculturais: "o sortilégio da cor", que pode ser traduzido por recalque, silêncio e negação da história. ${ }^{25}$

No volume dos $1^{\circ}$ e $2^{\circ}$ ciclos do Ensino Fundamental ( $1^{\mathrm{a}}$ a $4^{\mathrm{a}}$ séries), a proposta do eixo temático "História Local e Cotidiano" pressupõe o objetivo de identificar diferenças culturais entre o modo de vida da localidade do aluno e o de uma comunidade indígena que vive ou viveu na região. Fala-se de diferenças culturais, mas não se mencionam brancos e negros. As duas imagens que abrem e fecham o texto "Ensino e aprendizagem de História no primeiro ciclo" parecem prosaicas e sem relação com os argumentos historiográficos: na primeira, uma fotografia, aparecem crianças negras colorindo um painel a "Zumbi, o chefe do quilombo"; na segunda, um códice mostra "múltiplas ocupações de um menino asteca". ${ }^{26}$ A pergunta é óbvia: por que Zumbi e um menino asteca seriam exemplos de história local e cotidiano? Aqui se repetiu a regra da historiografia didática: a imagem como ilustração se deteriora numa representação sem contexto e sem história. ${ }^{27}$

Noutro volume, o tema transversal "Pluralidade Cultural" é justificado pela caracterização da população brasileira, formada por "descendentes dos povos africanos”. Depois, estabelece-se a crítica à interpretação do Brasil pela homogeneidade cultural e ao mito da democracia racial, uma vez que "essas interpretações conduziram a atitudes de dissimulação do quadro de todo existente: um racismo difuso, porém efetivo, com repercussões diretas na vida cotidiana da população discriminada". ${ }^{28}$ A seguir, arrola-se uma lista dos conhecimentos que possibilitariam o estudo da pluralidade cultural no âmbito

\footnotetext{
${ }^{24}$ A trilha do círculo vicioso é explicada no longo capítulo 3 do livro de Helio Santos, A Busca de um Caminho para o Brasil, op. cit., p. 61-177.

25 "Complemento do silêncio, outra forma e sintoma do racismo está no processo de tornar invisível a presença do afrodescendente na qualidade de ator, criador e transformador da história e da cultura nacionais. Esse tema perpassa a pesquisa, pois manifesta-se em relação a quase todos os aspectos da vida brasileira, a começar pela educação". Elisa Larkin Nascimento, $O$ Sortilégio da Cor: identidade, raça e gênero no Brasil, São Paulo, Selo Negro, 2003, p. 23.

${ }^{26}$ MEC, Parâmetros Curriculares Nacionais, Vol. 5: "História e Geografia", Brasília, Secretaria de Educação Fundamental, 2000, p. 48-60.

${ }^{27}$ Ver Circe Bittencourt, "Livros Didáticos entre Textos e Imagens", O Saber Histórico na Sala de Aula, São Paulo, Contexto, 2001, p. 69-90.

${ }^{28}$ MEC, Parâmetros Curriculares Nacionais, Vol. 10.3 ("Pluralidade Cultural”), Brasília, Secretaria de Educação Fundamental, 2001, p. 125.
} 
da escola: conhecimentos jurídicos, históricos e geográficos, sociológicos, antropológicos, populacionais, psicológicos e pedagógicos. Como se fosse pouca coisa para as 24 horas do professor de História, ainda se menciona o estudo das linguagens e das representações. ${ }^{29}$

No que tange aos conhecimentos históricos, exemplifica-se com o continente africano, mas no passado mítico e remoto, e não se menciona a África contemporânea. Admite-se a enorme complexidade da história da África "do período pré-colonial, como arqueologia: grupos humanos; civilizações antigas do Sudão, do sul e do norte da África”. No advento da modernidade capitalista, colocam-se outras complexidades, "a escravidão e a mercantilização". ${ }^{30} \mathrm{~A}$ única questão contemporânea é a teórica, com a substituição do conceito de raça pelo de etnia. Pode-se dizer que, apesar desta representação singela da África, a diversidade continental foi garantida. Como fica claro nos objetivos de conhecer a "diversidade do patrimônio etnocultural brasileiro", assim como as "origens continentais das diferentes populações do Brasil". Entretanto, ao se mencionar que o ensino e a aprendizagem, na perspectiva da pluralidade cultural, necessitam de uma suprema ética, além dos costumes, a proposta ganha aura de catecismo da história sagrada: "a prática do desvelamento é decisiva na superação da discriminação. Exige do professor discernimento, sensibilidade, intencionalidade e informação". Tudo isto para responder à questão motivadora, "ensinar a pluralidade ou viver a pluralidade?". ${ }^{31}$ Ora, doses de voluntarismo e capacidade informativa do professor não são as melhores ferramentas para uma história das relações étnico-raciais ou para se estudar a matriz cultural africana. Ainda se percebe, portanto, que a fala institucional elege devoção, vocação e não a profissão como a sustentabilidade da cultura escolar, o que talvez explique as enormes resistências aos procedimentos dos parâmetros e das diretrizes. Enfim, a impressão que fica, depois da leitura de um novo documento pedagógico brasileiro, é que a pluralidade cultural pode enraizar ainda mais a doxa da democracia racial, em vez de retirar suas vestes de ciência. ${ }^{32}$

\footnotetext{
${ }^{29}$ Fortes críticas ao "centralismo, ao excesso de burocracia e à falta de novidade" nas mudanças educacionais da década de 1990 podem ser vistas em Margarida Dias de Oliveira (org.), Contra o Consenso: LDB, DCN, PCN e reformas no ensino, João Pessoa, Associação Nacional de História/Núcleo da Paraíba, 2000.

${ }^{30}$ MEC, Parâmetros Curriculares Nacionais, Vol. 10.3, op. cit., p. 129-135.

${ }^{31}$ Idem, ibidem, p. 139.

${ }^{32}$ Uma excelente discussão sobre esta questão consta em Elisabeth Fernandes de Souza, "Repercussões do discurso pedagógico sobre relações raciais nos PCNs", Eliane Cavalleiro, Racismo e Anti-Racismo na Educação: repensando nossa escola, op. cit., p. 39-63.
} 
As Diretrizes Curriculares Nacionais para o Ensino Médio, cuja resolução foi aprovada pela Câmara de Educação Básica, em 26 de junho de 1998, indicam situações generalistas sobre o fenômeno da etnicidade, embora apontem para os fundamentos da ordem democrática. No parecer favorável ao projeto de resolução, a conselheira Guiomar Namo de Mello, depois de fazer uma longa citação de Platão, que conta o mito de como os homens conseguiram o conhecimento das artes com o fogo e conheceram as virtudes cívicas para realizarem a Pólis, aponta os fundamentos estéticos, políticos e éticos do "novo ensino médio brasileiro". O primeiro, "estética da sensibilidade", facilitaria o reconhecimento e a valorização da diversidade cultural do Brasil e das "formas de perceber e expressar a realidade própria dos gêneros, das etnias, e das muitas regiões e grupos sociais do país". Esta estética valorativa seria, segundo a conselheira, o substrato para "uma pedagogia que se quer brasileira, portadora de riqueza de cores, sons e sabores deste país". O segundo, "política de igualdade", seria ao mesmo tempo inspirador dos conteúdos curriculares e das práticas de ensino,

(...) sempre que nas ciências, nas artes, nas linguagens estiverem presentes os temas dos direitos da pessoa humana, do respeito, da responsabilidade e da solidariedade, e sempre que os significados dos conteúdos curriculares se contextualizarem nas relações pessoais e práticas sociais convocatórias da igualdade.

O terceiro, "ética da identidade", a partir de um humanismo revigorado, reconheceria que a educação é um processo de construção de identidades:

Educar sob inspiração da ética não é transmitir valores morais, mas criar as condições para que as identidades se constituam pelo desenvolvimento da sensibilidade e pelo reconhecimento do direito à igualdade a fim de que orientem suas condutas por valores que respondam às exigências do seu tempo. ${ }^{33}$ (grifos meus)

Com efeito, o postulado destes fundamentos é o diálogo no qual Platão coloca frente a frente Sócrates e Protágoras, em que o primeiro convence o segundo de que, sendo possível ensinar a virtude, ela não seria outra coisa senão a sabedoria e seu compromisso com a verdade. Lembremos apenas que este postulado foi o vetor de que somente os atenienses teriam a sabedoria das coisas da Cidade, cabendo às outras "raças" algum

${ }^{33}$ Parecer CNE/CEB 15/98, aprovado pela Câmara de Educação Básica em $1^{\circ}$ de junho de 1998. Publicado em Clarice Nunes, Diretrizes Curriculares Nacionais: ensino médio, Rio de Janeiro, DP\&A Editora, 2002, p. 53-64. 
tipo de qualidade bárbara. A longa duração de uma filosofia espiritualista negaria as portas da História ao continente africano, quando Hegel, o último helenista convicto, diria que a África não passava de um rebento de selvageria, "envolvido na escuridão da noite, aquém da luz da história consciente". ${ }^{34}$

Assim, a aparelhagem conceitual universalista, embora seja necessária para estabelecer princípios republicanos e democráticos na cultura escolar, precisa ser regada pela crítica de realidade temporal da história. Colocar, de vez, a etnicidade na sala de aula seria a própria realização dos enormes esforços que, na década de 1990, tentaram plantar a matriz cultural africana na agenda escolar brasileira. Seria possível, então, falar-se de uma cultura histórica comum às nossas matrizes culturais? A resposta será sempre negativa, enquanto não se "romper com uma história autocentrada, no nacional, na Europa, na religião cristã, na cultura branca". ${ }^{35}$ Hebe Mattos, especialista nos estudos sobre escravidão, aponta para uma agenda de quatro prioridades: a primeira seria criar "condições para uma abordagem da história da África no mesmo nível de profundidade com que se estuda a história européia e suas influências sobre o continente americano"; a segunda passa por "historicizar o processo de racialização dos negros nas Américas, em suas relações com a memória da escravidão, e suas implicações em termos de definição de direitos civis nos países do continente"; a terceira, "incorporar, à formação de professores, a historiografia mais recente sobre a história da escravidão no Brasil"; e, por fim, a quarta, de forma mais incisiva, incorporar "à formação de professores do ensino fundamental as novas pesquisas que abordam, historicamente, experiências concretas de criação e de transformações culturais identitárias, na experiência da diáspora africana". ${ }^{36}$ Trata-se sem dúvida de uma agenda que

\footnotetext{
${ }^{34}$ G. W. F. Hegel, Filosofia da História, Brasília, Editora UnB, 1995, p. 73-92. O historiador africanista deveria, por isto, renunciar a Hegel? Pelo contrário, deve estudá-lo profundamente, pois o historiador deve estar consciente de que todo pormenor factual carrega em si um princípio geral que lhe subjaz. Isto é hegeliano. Além do mais, o pensamento de Hegel sobre a história começa pela ironia e, assim, ele imaginou três categorias de atores históricos: grandes, pequenos e depravados (heróis, homens medianos e criminosos). O tráfico, a escravidão e o racismo seriam, por acaso, elevações do Espírito ou alterações nas condições de produção? Ver as análises de E. H. Gombrich, Para uma História Cultural, Lisboa, Gradiva, 1994, p. 35-67; e Hayden White, Meta-História: a imaginação histórica do século XIX, São Paulo, Edusp, 1992, p. 95-144.

${ }^{35}$ Lana Mara de Castro Siman, "Os currículos e as novas fronteiras da história", Anais do XX Simpósio da Associação Nacional de História, Florianópolis, ANPUH, 1999, p. 245-258.

${ }^{36}$ Hebe Maria Mattos, "O Ensino de História e a luta contra a discriminação racial no Brasil", Martha Abreu e Rachel Soihet (orgs.), Ensino de História: conceitos, temáticas e metodologia, Rio de Janeiro, Casa da Palavra, 2003, p. 127-136.
} 
implica uma pequena revolução historiográfica nos três níveis do ensino de História: fundamental, médio e superior. Os historiadores estariam dispostos a remover os entulhos essencializados que ainda imperam na Casa de Clio?

Por isto que as lutas culturais e jurídicas ainda estão na ordem do dia dos protagonismos africanistas. Como já me referi antes, a Lei n ${ }^{\circ} 10.639$, de 9 de janeiro de 2003, foi um passo importante para o ensino de História da África. ${ }^{37}$ Ela ordena a reconfiguração curricular e tende a influir na cultura escolar, na medida em que se desdobrou nas diretrizes culturais para este novo século. Pode-se dizer que a determinação legal tem estimulado projetos editoriais e que obras surgidas de experiências afrocentristas começam a ficar acessíveis para professores e alunos no campo historiográfico. ${ }^{38}$

Nesta conjuntura quente sobre as ações afirmativas, destaca-se a homologação da Resolução n ${ }^{\circ}$, de 17 de junho de 2004, pelo Conselho Federal de Educação, que institui as Diretrizes Curriculares Nacionais para a Educação das Relações Étnico-Raciais e para o Ensino de História e Cultura AfroBrasileira e Africana. Os relatores sustentaram "políticas de reparações, de reconhecimento e valorização de ações afirmativas" e, no âmbito da educação das relações étnico-raciais, apontam para a ressignificação do conceito raça no contexto das lutas anti-racistas. Os valores da africanidade são continuamente destacados nas Diretrizes, mas não se pode dizer que isto é feito a partir de argumentos essencialistas. Entendo que a crítica ao cânone sociológico Gilberto Freyre sempre reiterou nos prefácios de seus livros que fazia História Social - é consoante à forma com a qual historicamente o pensamento social brasileiro interpretou a nação, feita, construída e imaginada: "Ainda persiste em nosso país um imaginário étnico-racial que privilegia a brancura e valoriza principalmente as raízes européias da sua cultura, ignorando ou pouco

\footnotetext{
${ }^{37}$ O conteúdo programático de História e Cultura Afro-Brasileira deve incluir, conforme manda a lei, o estudo de História da África e dos africanos, a luta dos negros no Brasil, a cultura negra brasileira e o negro na formação da sociedade nacional. Ainda determina a lei que os conteúdos sobre a matriz cultural africana sejam ministrados no "âmbito de todo o currículo escolar, em especial nas áreas de Educação Artística e de Literatura e História Brasileiras". Também institui no calendário escolar o 20 de novembro como o "Dia Nacional da Consciência Negra". O texto integral da lei pode ser obtido no link "Legislação Educacional" do portal do Ministério da Educação, www.mec.gov.br.

${ }^{38}$ Como por exemplo: Leila Leite Hernandez, A África na Sala de Aula: visita à história contemporânea, São Paulo, Selo Negro, 2005; Nei Lopes, Enciclopédia Brasileira da Diáspora Africana, São Paulo, Selo Negro, 2004; Mary Del Priore e Renato Pinto Venâncio, Ancestrais: uma introdução à história da África atlântica, Rio de Janeiro, Campus, 2004.
} 
valorizando as outras, que são a indígena, a africana e a asiática". ${ }^{39} \mathrm{O}$ texto das Diretrizes sustenta que a pragmática para o ensino de História e Cultura AfroBrasileira e Africana deve partir dos seguintes princípios: 1. consciência política e histórica da diversidade; 2 . fortalecimento de identidades e de direitos; e 3. ações educativas de combate ao racismo e a discriminações. ${ }^{40}$

No que concerne à História da África, destaca-se a sugestão para o estudo de temáticas em torno da modernidade, privilegiando-se as grandes teses do Atlântico Negro: a ocupação colonial na perspectiva dos africanos; a descolonização e seus impactos na Europa e na América; as relações entre as culturas e as histórias dos povos do continente africano e os da diáspora; vida e existência cultural e histórica dos africanos e seus descendentes na América; relações políticas, econômicas, culturais e educacionais entre a África e o Brasil. O texto também encaminha para estudos de caso e pesquisas biográficas sobre o protagonismo de políticos, cientistas, escritores e intelectuais africanos, na perspectiva de superar a representação de uma África sem criação tecnológica, tradição artística e luta social. ${ }^{41}$ Sugere-se que as universidades incluam disciplinas em seus cursos, criem grupos de estudo e de pesquisa e que realizem avaliações sistemáticas sobre as experiências em processo.

\section{Considerações finais}

Creio ter conseguido articular os campos de produção do conhecimento histórico e das representações étnico-raciais definidos neste ensaio. A pesquisa, o ensino acadêmico, a legislação e as diretrizes educacionais foram vistos nas suas circularidades e atravessamentos. Não tive intenção de tratá-los como elementos hierarquizados, embora competências, formas, sentidos e intensi-

${ }^{39}$ MEC, Diretrizes Curriculares Nacionais para a Educação das Relações Étnico-Raciais e para o Ensino de História e Cultura Afro-Brasileira e Africana, Brasília, SEPPIR/SECAD/INEP, junho de 2005, p. 14.

${ }^{40}$ Desde a criminalização do racismo, pela Constituição de 1988, as lutas jurídicas anti-racistas tiveram como conseqüências lei estaduais e municipais. Nos estados da Bahia, do Rio de Janeiro e de Alagoas, as constituições estaduais reiteraram os preceitos do pluralismo étnico. Em Belém, Belo Horizonte, Recife, Rio de Janeiro, Aracaju e São Paulo, leis municipais aprovaram a inclusão de estudos da Raça Negra no currículo escolar. Na cidade de Belém, a lei determinou que o conteúdo relativo ao "estudo da Raça Negra na formação sociocultural brasileira" fosse ministrado na disciplina História. Ver legislação em Maria José Rocha e Selma Pantoja (orgs.), Rompendo Silêncios: história da África nos currículos da educação básica, Brasília, DP Comunicações, 2004, p. 109-134.

${ }^{41}$ MEC, Diretrizes..., op. cit., p. 22-23. 
dades sejam sempre contatos de tensão e de historicidades dramáticas. Dito isto, deve-se acrescentar que a ciência que professamos, a História, terá de ser, doravante, além de eticamente correta nas suas problematizações, etnicamente interessada no protagonismo dos africanos e dos afro-brasileiros. Sem nenhum otimismo exagerado, sob pena de receber acusação do tipo "ingênuo da raça", considero que a ciência que professamos tem contribuído de alguma forma para a crítica ao cânone da mestiçagem.

Porém não descarto como hipótese verossímil o fato de que instituições científicas e comunidades de saberes tendem a ser conservadoras em suas normas e costumes, de modo que são as próximas gerações de estudantes em formação que têm a incumbência histórica de demonstrar que o Brasil ainda não é uma democracia racial e que não haverá República se a matriz cultural africana esbarrar na seleção cultural e científica. Na verdade, esta luta deve ser de todos os homens e mulheres com humanidade no rosto: democracia racial para concretizar uma nação que, para além de mestiça, seja reconhecidamente multirracial e, portanto, também negra. Há cientistas, historiadores, professores e alunos que ainda não pensam desta maneira, suplico-lhes então que leiam e reflitam sobre o que escreveram dois africanos, um negro e outro branco, ao evocarem um não menos notável afro-americano.

Nelson Mandela, sul-africano, ao receber o Prêmio Nobel da Paz, em 1993:

Mas ainda permanece a esperança de que também estes sejam abençoados com razão suficiente para entender que a história não será negada e que a nova sociedade não poderá ser criada pela repetição de um passado repugnante, ainda que refinado ou sedutoramente maquiado. (...) Que as aspirações de todos nós provem que Martin Luther King, Jr. estava certo quando disse que a humanidade já não poderia estar tragicamente ligada à noite sem estrelas do racismo e da guerra. ${ }^{42}$

José Eduardo Agualusa, angolano, ao finalizar seu último romance, em 2004:

Vem-me à memória a imagem a preto e branco de Martin Luther King discursando à multidão: eu tive um sonho. Ele deveria ter dito antes: eu fiz um sonho. Há alguma diferença, pensando bem, entre ter um sonho e fazer um sonho. Eu fiz um sonho. ${ }^{43}$

${ }^{42}$ Nelson Mandela, "Discurso de aceitação e conferência do Nobel”, Emir Sader e Cláudia Mattos (orgs.), Declarações de Paz em Tempos de Guerra, Rio de Janeiro, Bom Texto, 2003, p. 191-192.

${ }^{43}$ José Eduardo Agualusa, O Vendedor de Passados, Rio de Janeiro, Gryphus, 2004, p. 198-199. 